\title{
Sensitive and immunogen-specific serological detection of Rodentibacter pneumotropicus infections in mice
}

Felix Fingas ${ }^{1,2}$, Daniela Volke ${ }^{1,3}$, Rayk Hassert ${ }^{1,3}$, Juliane Fornefett ${ }^{4}$, Sophie Funk ${ }^{4}$, Christoph Georg Baums ${ }^{3,4}$ and Ralf Hoffmann ${ }^{1,3,5^{*}}$ (1)

\begin{abstract}
Background: Rodentibacter (R.) pneumotropicus colonizes the respiratory and urogenital tracts of laboratory mice with a reported moderate serological prevalence from 4 to 13\%. Thus, regular tests to identify this pathogen in mice are recommended for animal facilities. However, a recent study indicated that current serological assays are partly insensitive, as C57BL/6 and BALB/c mice infected with $R$. pneumotropicus were incorrectly screened as seronegative.

Results: Here, we report a systematic analysis of protein and lipopolysaccharides antigens by immunoblot and ELISA that allowed establishing a sensitive test system able to differentiate between $R$. pneumotropicus and the closely related species $R$. heylii. Furthermore, the main immunogen, designated as 'characteristic antigen for Rodentibacter of laboratory origin 1' (CARLO-1), was identified by two-dimensional gel electrophoresis followed by immunoblot and tandem mass spectrometry in a preparation of outer membrane proteins. An indirect ELISA relying on the recombinantly expressed protein provided high sensitivity, specificity, and selectivity. The corresponding carlol gene was highly conserved (>97\%) among 21 isolates of $R$. pneumotropicus and $R$. heylii.

Conclusion: The newly identified protein CARLO-1 is well suited for the sensitive and specific serological detection of Rodentibacter infections in mice. Indirect differentiation of R. pneumotropicus and $R$. heylii infections may be possible using an ELISA based on a whole-cell antigen preparation. All four established ELISA systems using a whole-cell preparation, lipopolysaccharides, outer-membrane proteins and protein CARLO-1 as antigen, respectively, outperformed a commercial ELISA in terms of sensitivity.
\end{abstract}

Keywords: ELISA, CARLO-1, Rodentibacter pneumotropicus, Rodentibacter heylii, Pasteurella pneumotropica, FELASA, Health monitoring, Antigen, Two-dimensional gel electrophoresis

\section{Background}

Rodentibacter (R.) pneumotropicus [Pasteurella pneumotropica biotype Jawetz] [1] is a Gram-negative, rod-shaped bacterium of the Pasteurellaceae family that frequently colonizes the respiratory and urogenital tracts of laboratory mice and rats. The infection is mostly described as asymptomatic in immunocompetent mice [2], whereas immunodeficient and other genetically modified mice

\footnotetext{
*Correspondence: bioanaly@rz.uni-leipzig.de

${ }^{1}$ Institute of Bioanalytical Chemistry, Faculty of Chemistry and Mineralogy,

Universität Leipzig, Leipzig, Germany

${ }^{3}$ Center for Biotechnology and Biomedicine, Universität Leipzig, Leipzig,

Germany

Full list of author information is available at the end of the article
}

show mild to lethal disease with suppurative lesions in various organs [3]. However, we recently reported high morbidity and mortality in $\mathrm{C} 57 \mathrm{BL} / 6$ and $\mathrm{BALB} / \mathrm{c}$ mice upon infection with a strain isolated from a research facility indicating that the pathology of some $R$. pneumotropicus strains may have been underestimated [4]. Although the pathogen's environmental stability is very low [5] and transmission mainly depends on direct contact [2], moderate to high prevalence rates of 4 and 13\% are reported for laboratory mice in Europe and North America, respectively [6]. Hence, current guidelines of the Federation for Laboratory Animal Science Associations (FELASA) recommend

(c) The Author(s). 2019 Open Access This article is distributed under the terms of the Creative Commons Attribution 4.0 International License (http://creativecommons.org/licenses/by/4.0/), which permits unrestricted use, distribution, and reproduction in any medium, provided you give appropriate credit to the original author(s) and the source, provide a link to the Creative Commons license, and indicate if changes were made. The Creative Commons Public Domain Dedication waiver (http://creativecommons.org/publicdomain/zero/1.0/) applies to the data made available in this article, unless otherwise stated. 
quarterly testing to examine $R$. pneumotropicus infections in mice colonies [7].

The former Pasteurella (P.) pneumotropica biotypes Jawetz and Heyl were recently reclassified into separate species of the genus Rodentibacter, i.e., $R$. pneumotropicus and $R$. heylii, respectively [1]. Consequently, sensitive, specific and selective detection assays are required for both species. Current assays rely on direct differentiation based on color, morphological, and biochemical aspects of colonies [1], high-resolution melting curve analysis [8], and DNA amplification using polymerase chain reaction (PCR) [9-11]. Indirect $R$. pneumotropicus- or $R$. heylii-specific serological assays, such as enzyme-linked immunosorbent assay (ELISA), have not been described to the best of our knowledge. Currently, applied ELISA rely on inactivated whole cells detecting both $P$. pneumotropica biotypes Jawetz and Heyl $[12,13]$. Manning et al. reported a sensitive detection of $P$. pneumotropica antibodies based on a preparation of uncharacterized cell wall proteins, which were not examined for their specificity to Jawetz and Heyl isolates [14]. ELISA specificity among various members of Pasteurellaceae is linked to lipopolysaccharides (LPS), but properties differentiating Jawetz and Heyl species have also not been studied [15]. Vaccination studies identified repeats-in-toxin (RTX) exoproteins and outer membrane protein P6 as protective immunogens [16-18]. Here, we describe a systematic identification of immunogens used to develop a sensitive ELISA detecting specifically $R$. pneumotropicus and $R$. heylii together or only $R$. pneumotropicus without cross-reactivity towards other FELASA-listed bacteria.

\section{Results}

\section{Confirmation of seroconversion}

Previously, we reported that immunocompetent C57BL/ 6 and $\mathrm{BALB} / \mathrm{c}$ mice intranasally challenged with a $R$. pneumotropicus strain, recently isolated from a laboratory mouse of a German research facility, experienced high rates of morbidity and mortality [4]. Surprisingly, a commercial Pasteurella pneumotropica ELISA used for routine health monitoring did not detect Rodentibacter-specific antibodies in any of the 15 sera obtained 28 days post infection (dpi; Fig. 1a), although the pathogen was isolated from various organs. Furthermore, this ELISA identified only one of 18 sera from mice experimentally infected with $R$. heylii, providing an overall sensitivity of only 3\% (1/33) for both Rodentibacter species. Thus, an indirect ELISA using a whole-cell antigen (WCA) extract of the $R$. pneumotropicus strain used in the infection model was established (Fig. 1b), which correctly identified the $R$. pneumotropicus-infected mice with absorbance values ranging from 0.9 to 2.1 . The mean absorbance of $1.6 \pm 0.4$ obtained for C57BL/6 $(n=8)$ was slightly higher than for BALB/c mice $(1.4 \pm 0.3, n=7)$ compared to $0.11 \pm 0.02$ for $R$. heylii-infected mice $(n=18)$ and $0.07 \pm 0.005$ for uninfected SPF mice $(n=15$, control). Thus, the WCA-based ELISA was specific and sensitive (15/15) for R. pneumotropicus infections.

As the WCA-ELISA confirmed the seroconversion, the immunogenic components present in the cell extract were further characterized. When proteins present in the WCA preparation were digested with proteinase $\mathrm{K}$ (Fig. 2a), as confirmed by SDS-PAGE (30 kDa band corresponds to Protease $\mathrm{K}$ ), the remaining material was still recognized by sera obtained from both mouse strains in ELISA (Fig. 2b), but with significantly lower readouts. This clearly indicated that the immune system of C57BL/6 and BALB/c mice recognized both proteins and non-proteinogenic components present in the WCA preparation.

\section{Identification of immunogenic determinants of R. pneumotropicus}

Thus, cellular protein fractions and LPS were prepared by sarcosine differential solubility and phenol extraction, respectively, separated by SDS-PAGE and probed with sera of experimentally infected mice in immunoblots (Fig. 3).

The protein preparations differed in the band patterns with the number of visible bands decreasing from the Cyt fraction to IM and OM preparations (Fig. 3a). When the OM preparation was digested with proteinase $\mathrm{K}$, most dominant proteins disappeared except for a faint band at an apparent molecular weight of $\sim 35 \mathrm{kDa}$ and some weak bands in the lower part of the lane $(<25$ $\mathrm{kDa}$ ). A blot probed with sera of infected C57BL/6 and $\mathrm{BALB} / \mathrm{c}$ mice displayed a dominant band at $\sim 33 \mathrm{kDa}$ and the C57BL/6 serum an additional band at $\sim 60 \mathrm{kDa}$. Both bands also showed the highest relative intensities in the OM preparation. A negative serum stained two bands of low intensity at 30 and $37 \mathrm{kDa}$. When the corresponding gel bands were cut out (Fig. 3a, rectangles) and digested with trypsin, more than 25 proteins were identified by tandem mass spectrometry (Additional file 1). Interestingly, the two bands were invisible in the immunoblot of the proteinase K-treated $\mathrm{OM}$ fraction. Instead, a series of bands ranging from 30 $\mathrm{kDa}$ to the top of the gel appeared that were also visible in the IM and OM fractions but absent in the protein stain. This pattern was similar to the patterns obtained by glyco- and immunostaining of the LPS preparation (Fig. 3c). Remarkably, the OM and LPS preparations probed in an indirect ELISA were recognized by sera obtained from $R$. pneumotropicus-infected mice, but not from uninfected mice (Fig. 4).

The readouts of the OM-based ELISA ranged from 0.89 to 1.93 (mean: $1.41 \pm 0.34$ ) and the LPS-based 

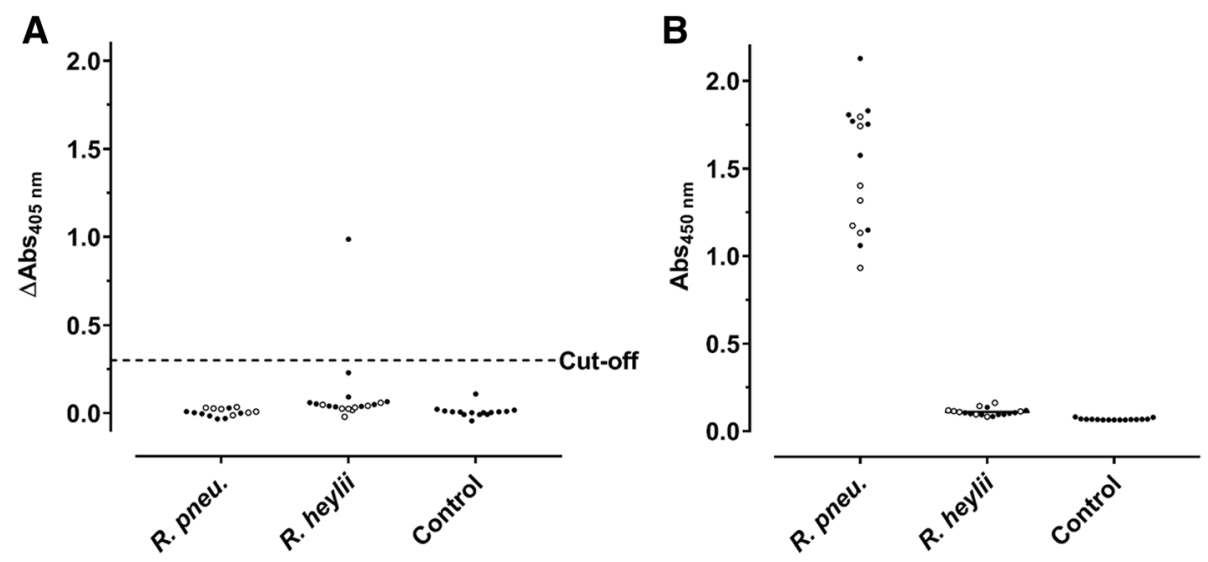

Fig. 1 Commercial (a) and WCA-based ELISA (b) results of sera obtained from C57BL/6 (full circles) and BALB/c mice (open circles) infected with R. pneumotropicus or $R$. heylii and uninfected animals. Test specific cut-off value for the commercial ELISA (0.3) is indicated as a dashed line. Similar results of a comparable WCA-ELISA for the R. pneumotropicus infected mice and respective controls shown in (b) have been published previously [4]

ELISA from 0.25 to 1.31 (mean: of $0.76 \pm 0.33$ ). When the OM-ELISA was probed with sera of mice infected with the closely related bacterium $R$. heylii, all absorbance values were above the LOD (mean: $0.37 \pm 0.11$ ). In contrast, the LPS-ELISA recognized only one of the 15 sera slightly above the LOD (mean value $0.06 \pm 0.01$ ). Thus, $R$. pneumotropicus infections appear to trigger a highly specific immune response against LPS that might be applied for the serological differentiation from the closely related species $R$. heylii. However, LPS can be strain-specific and is for example used in the serotyping of Pasteurella multocida. Thus, a serological detection solely based on LPS may miss infections with some $R$. pneumotropicus strains.

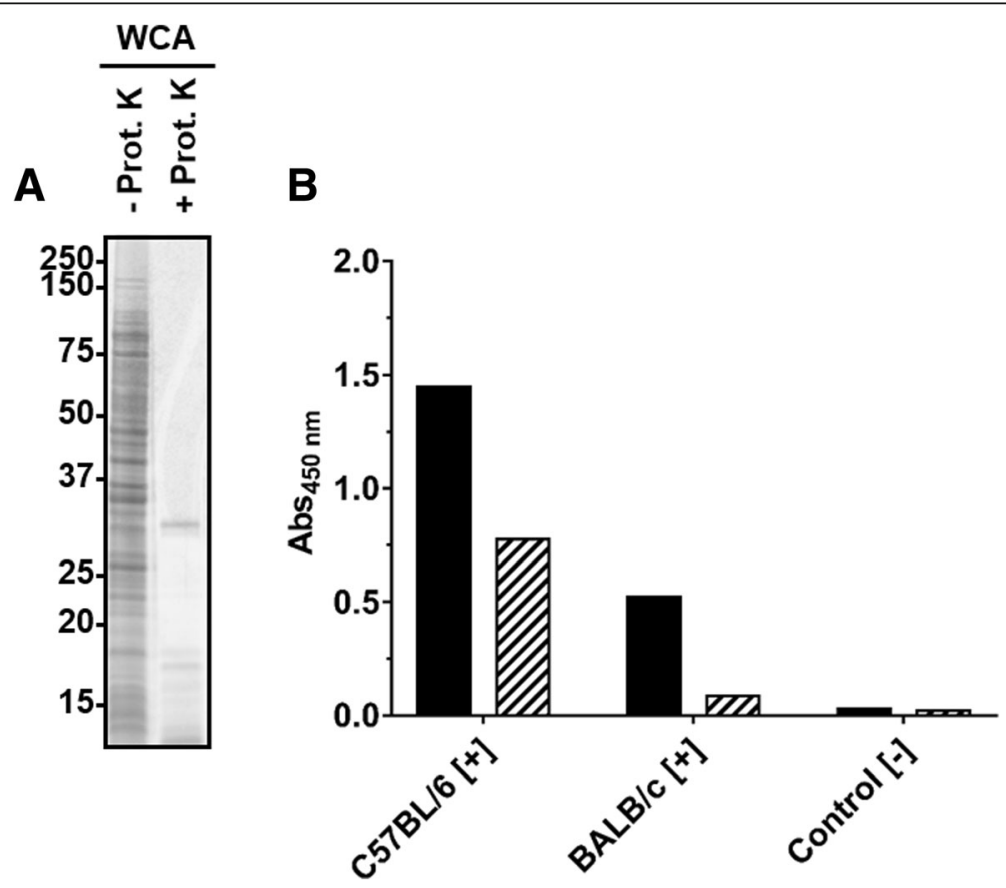

Fig. 2 SDS-PAGE (a) and ELISA (b) of a WCA preparation incubated $\left(56^{\circ} \mathrm{C}\right.$, overnight) in the absence or presence of proteinase $\mathrm{K}$. a) Oriole stain of a WCA preparation obtained from R. pneumotropicus strain JF4Ni separated by SDS-PAGE before $(-)$ and after (+) proteinase K digestion. b) Indirect ELISA using WCA (black) and digested WCA (hatched) probed with sera of experimentally infected C57BL/6 and BALB/c mice and a control serum 


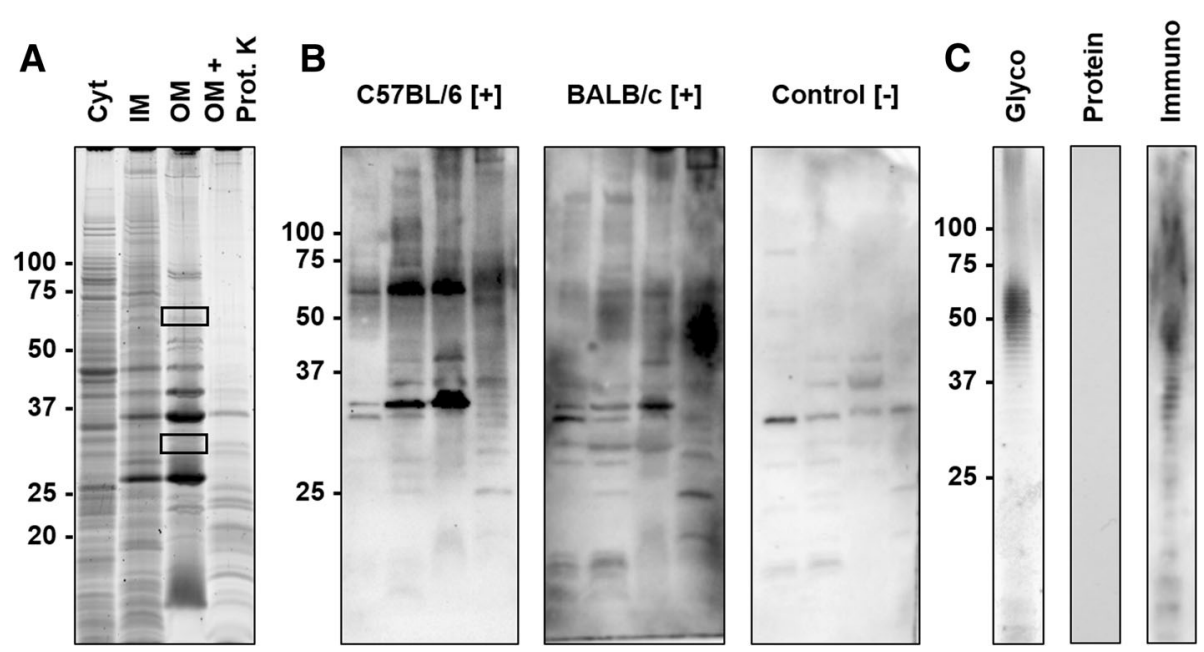

Fig. 3 SDS-PAGE and corresponding blots of protein and LPS preparations. a) SDS-PAGE of cytosolic (Cyt), sodium N-laurylsarcosinate (SLS)soluble membrane (inner membrane, IM), SLS-insoluble membrane (outer membrane, OM) preparations, and the OM preparation digested with Proteinase K (OM + Prot. K). Proteins were stained with Oriole. Gel areas cut out to identify the proteins by mass spectrometry (MS) are indicated by rectangles. b) Immunoblots probed with sera obtained from C57BL/6 and BALB/c mice experimentally infected with $R$. pneumotropicus ([+]) and an uninfected BALB/c mouse (control [-]) c) SDS-PAGE of the LPS preparation stained with Pro-Q Emerald (Glyco) or Coomassie (Protein) and the corresponding immunoblot using serum of an infected C57BL/6 mouse (Immuno). Molecular weights (kDa) of the marker proteins are indicated left

\section{Identification of immunogenic proteins of \\ R. pneumotropicus}

As the bands recognized by the immune sera after SDS-PAGE contained many proteins, an SDS-lysed cell pellet (SCP) of $R$. pneumotropicus was separated by two-dimensional gel electrophoresis (2-DE) and probed with sera obtained from experimentally infected mice and controls (Fig. 5).

Proteins were well separated in both dimensions and only a few obviously specific signals were observed in the immunoblots probed with sera obtained from infected $\mathrm{C} 57 \mathrm{BL} / 6$ and BALB/c mice. The spots detected at an apparent molecular weight of $\sim 33 \mathrm{kDa}$ and a $\mathrm{pH}$ range from 9 to 10 were identical for sera obtained from both mouse lines. The previously observed signal at 60 $\mathrm{kDa}$ for $\mathrm{C} 57 \mathrm{BL} / 6$ mice (Fig. 3b, left panel) was also present as a faint series of spots in the acidic part of the gel. Intense spots of immunoblots were matched to a Coomassie stained gel and the corresponding spots were cut and digested with trypsin. Mass spectrometry identified only outer membrane protein A (OmpA). When the $\mathrm{OM}$ fraction was applied to 2-DE, similar patterns in immunoblot were observed (data not shown). However, tandem MS identified two additional outer membrane
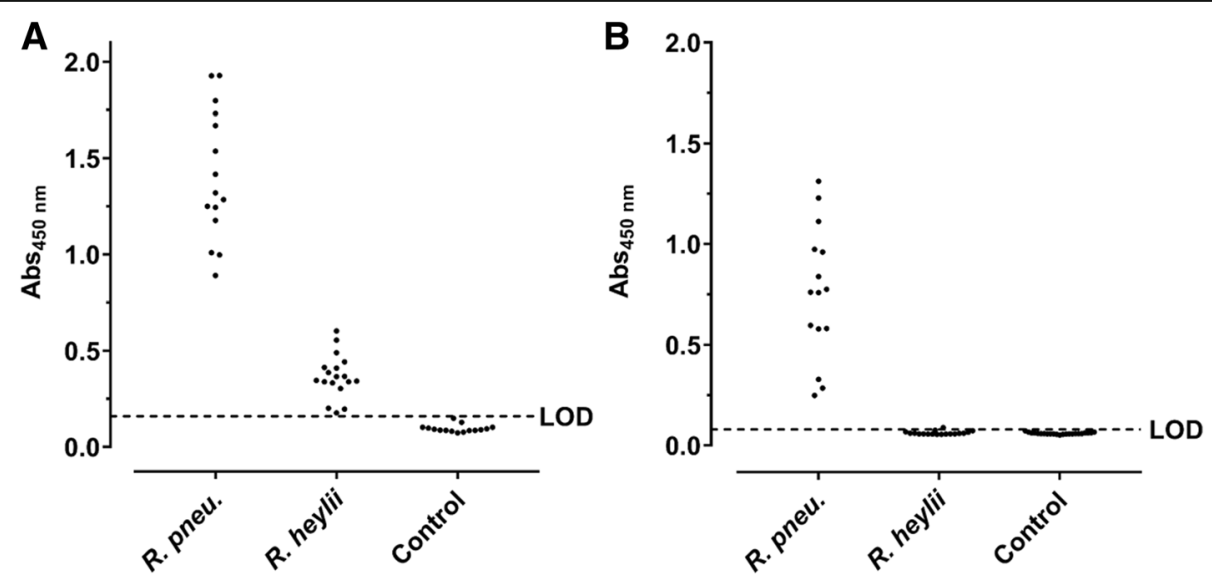

Fig. 4 Indirect ELISA based on OM (a) and LPS preparations (b) probed with sera from C57BL/6 and BALB/c mice experimentally infected with R. pneumotropicus or R. heylii and uninfected SPF mice (Control). The LODs of OM- (0.16) and LPS-ELISA (0.08) based on the absorbance of control sera are indicated as dashed lines. No differences were observed between the used mouse strains 

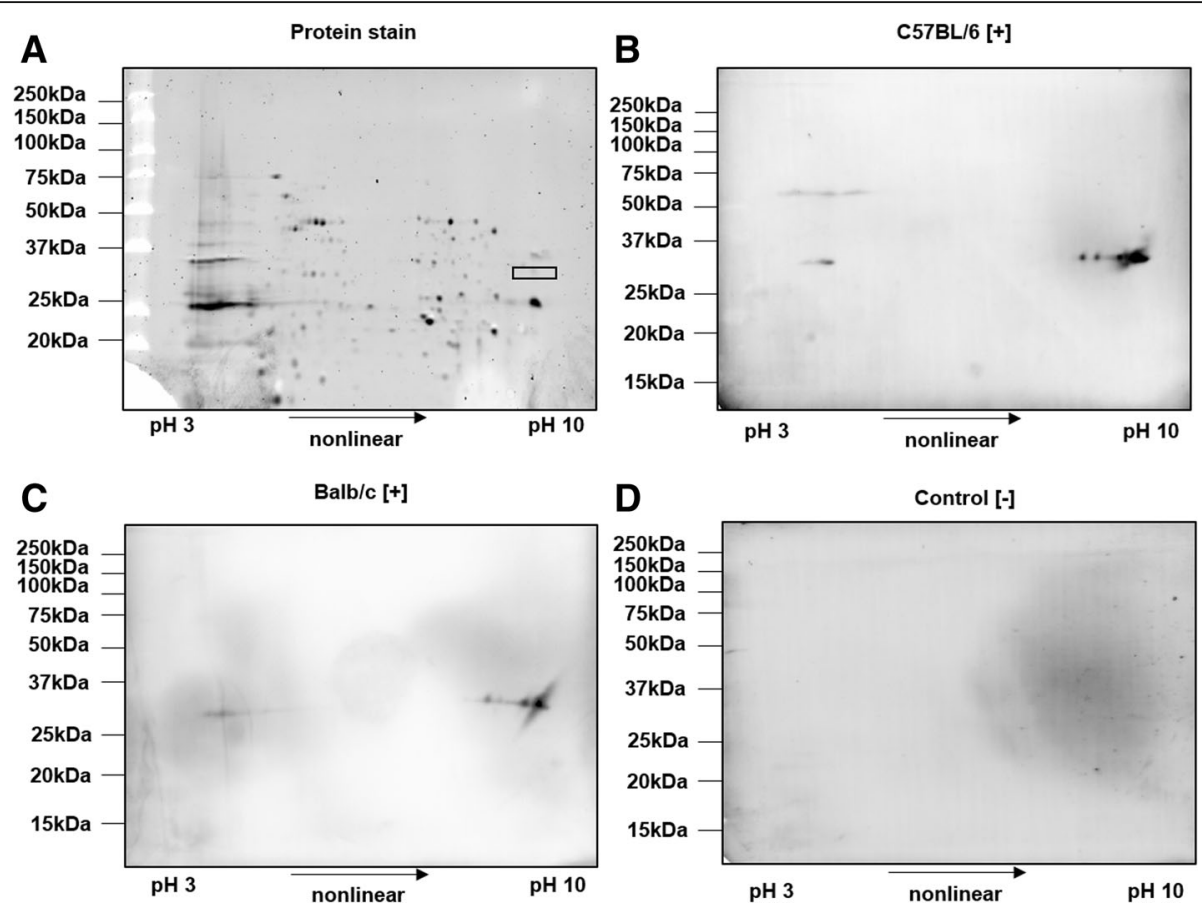

Fig. 5 2-DE of SCP of $R$. pneumotropicus stained with Oriole (a) and corresponding immunoblots probed with sera obtained from infected C57BL/6 (b) and BALB/c mice (c) and a non-infected C57BL/6 mouse (control, d). Molecular weights of the marker proteins are indicated on the left site. The gel spot area for protein identification by tandem MS is indicated by a rectangle

proteins, i.e., long-chain fatty acid transport protein (FadL) and a hypothetical protein (HP), with protein scores above 1000 (Table 1 and Additional file 2).

\section{Expression and verification of immunogenic proteins}

The three presumed immunogenic proteins (Table 1) of $R$. pneumotropicus were expressed in E. coli as recombinant $(\mathrm{r})$ proteins with $\mathrm{N}$-terminal Strep- and C-terminal His-tags. Expression and identity of all three full-length proteins were confirmed by immunoblots after SDS-PAGE using Strep-Tactin or an anti-His-Tag antibody and mass spectrometry after in-gel digestion (Additional files 3, 4, 5). When probed with sera of $R$. pneumotropicus-infected mice, only Strep-rHP-His showed a strong specific signal. The solubilized protein (Additional file 6) was purified by IMAC yielding $0.18 \mathrm{mg}$ pure protein, as indicated by a main band at an apparent molecular weight of $37 \mathrm{kDa}$ (calculated: $34.8 \mathrm{kDa}$ ) in SDS-PAGE (Additional file 7), which was also confirmed by tandem mass spectrometry after in-gel digestion (protein score $>23,000$, sequence coverage $\sim 75 \%$, Additional file 2). The faint band at $30 \mathrm{kDa}$ contained ribosomal protein L2 of E. coli.

\section{Protein-based ELISA}

When coated in an indirect ELISA, sera of mice infected with $R$. pneumotropicus generated absorbance values ranging from 0.85 to 2.15 and 0.43 to 1.35 with mean absorbance values of $1.67 \pm 0.47$ and $0.87 \pm 0.31$ for C57BL/6 and BALB/c mice, respectively (Fig. 6). Sera of mice infected with $R$. heylii provided absorbance values ranging from 0.53 to 1.52 and 0.19 to 0.96 with mean absorbance values of $1.04 \pm 0.36$ and $0.64 \pm 0.26$ for $\mathrm{C} 57 \mathrm{BL} / 6$ and $\mathrm{BALB} / \mathrm{c}$ mice, respectively. This indicates mouse strain specific immune responses upon Rodentibacter infections. Sera of uninfected control mice $(n=26)$ resulted in a mean absorbance value of $0.19 \pm$ $0.09(\mathrm{LOD}=0.47)$ with all sera tested below 0.43. Thus, 92\% (94\%) of the sera obtained from mice infected with $R$. pneumotropicus ( $R$. heylii) were correctly identified with absorbance values above the LOD. However, the Strep-rHP-His-ELISA could not distinguish infections

Table 1 Proteins identified in spots after 2-DE corresponding to spots of the immunoblots

\begin{tabular}{|c|c|c|c|c|c|}
\hline Sample & Protein & Accession number & Molecular weight $(\mathrm{kDa})$ & Protein score & Sequence coverage \\
\hline$\overline{S C P}$ & OmpA & WP_018357032.1 & 37.5 & 4979 & $61.3 \%$ \\
\hline $\mathrm{OM}$ & FadL & WP_018355328.1 & 48.1 & 2224 & $57.1 \%$ \\
\hline $\mathrm{OM}$ & $\mathrm{HP}$ & WP_018356225.1 & 34.0 & 1981 & $52.9 \%$ \\
\hline
\end{tabular}




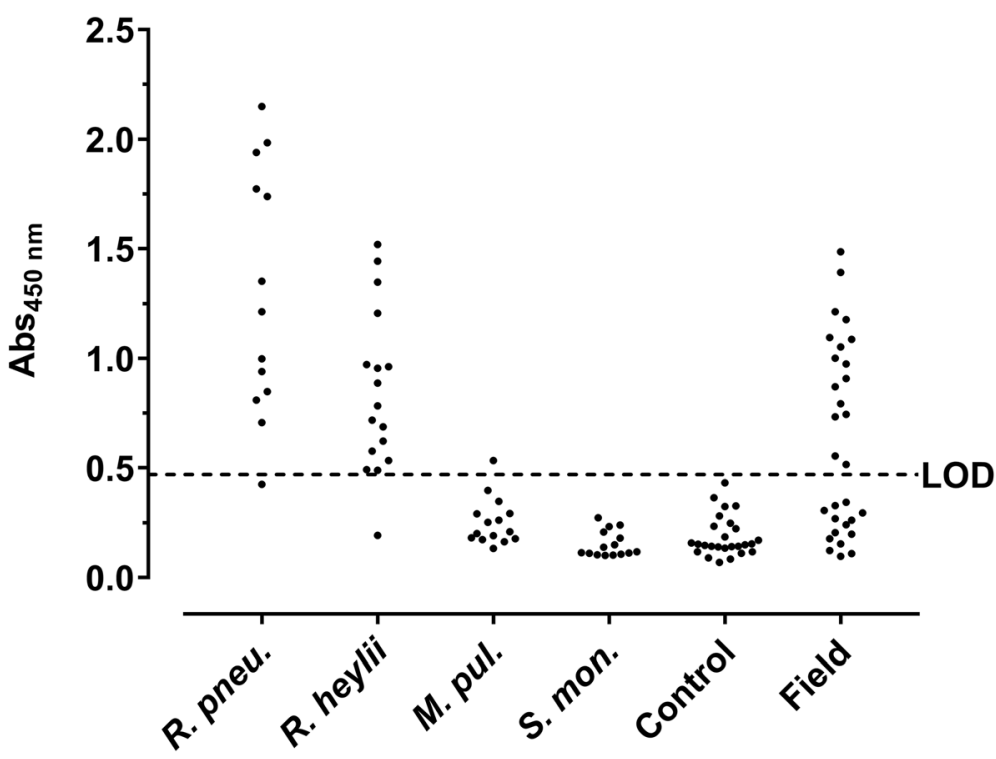

Fig. 6 Protein-based ELISA. Strep-rHP-His was coated and probed with sera from mice experimentally infected with R. pneumotropicus (R. pneu.), R. heylii, M. pulmonis (M. pul.), and S. moniliformis (S. mon.), sera of uninfected mice (Control), and with field sera. The dashed line indicates the $\operatorname{LOD}(0.47)$

with the two closely related Rodentibacter species. Nevertheless, the antigen was not cross-reactive against serum samples obtained from mice tested positive for other FELASA-listed bacterial pathogens, namely $M$. pulmonis $(n=15)$ and S. moniliformis $(n=15)$. Only one of these 30 sera showed an absorbance slightly above the LOD. Thus, Rodentibacter infections were detected with high sensitivity and specificity in the probed serum samples using Strep-rHP-His. The diagnostic parameters of the developed ELISA are summarized in Table 2.

When serum samples $(n=30)$ obtained from one unit of a German animal facility with acute $R$. pneumotropicus infection, confirmed partially by PCR, cultivation and MALDI-ToF (Additional file 8), were tested, 16 sera were identified as seropositive (Fig. 6, panel 'field') compared to only two sera identified positive by a commercial Pasteurella pneumotropica ELISA (Additional file 9).

Table 2 Diagnostic parameters of the indirect Strep-HP-His-ELISA

\begin{tabular}{ll}
\hline Diagnostic parameter & Value \\
\hline Intra-assay CoV & PC: $5.0 \%(n=42)$ \\
& NC: $5.6 \%(n=42)$ \\
Inter-assay CoV & PC: $5.3 \%(n=5)$ \\
& NC: $4.2 \%(n=5)$ \\
LOD & 0.47 \\
DSn & $93.3 \%(n=30)$ \\
DSp & $100 \%(n=26)$ \\
Selectivity & $96.7 \%(n=30)$ \\
\hline
\end{tabular}

\section{Conservation of HP on the DNA level in murine Rodentibacter isolates}

The sequence encoding HP in the genomic DNA was confirmed in Rodentibacter isolates classified as R. pneumotropicus $(n=11)$ or $R$. heylii $(n=10)$ by PCR [19] (Additional files 10 and 11). Sanger sequencing of the PCR products revealed sequence identities of at least $97 \%$ for all tested isolates compared to the $R$. pneumotropicus type strain ATCC35149. Based on the high conservation and the immunogenic character of the identified hypothetical protein HP, it was designated as 'characteristic antigen for Rodentibacter of laboratory origin 1' and termed CARLO-1.

\section{Discussion}

The recent reclassification of [Pasteurella pneumotropica] biotypes Jawetz and Heyl into $R$. pneumotropicus and $R$. heylii [1], respectively, demands a sensitive, specific and selective detection of both pathogens in laboratory mice. So far, the morphological and biochemical differentiation of both species is often inconclusive and, hence, difficult within the manifold Pasteurellaceae family [20]. The surprisingly low sensitivity of the applied commercial ELISA observed for confirmed positive sera of R. pneumotropicus and $R$. heylii as well as for field sera, may lead to many undetected infections. The WCA-based ELISA established by our group appears to provide a much higher sensitivity and to differentiate defined positive sera of the two closely related Rodentibacter species. Apparently, the new test improves previously reported WCA-based ELISA protocols [12, 21]. Generally, the reported prevalence may be influenced by insensitive 
ELISA assays used in routine health monitoring, as shown here for one commercial assay.

Isolated LPS of $P$. multocida has been shown to be highly protective in mice [22] and was successfully applied as antigen in indirect ELISA and immunoblot for the detection of $P$. multocida infections [23, 24]. However, the LPS isolates were specific for a few serotypes and missed other serotypes, which prevents their general application. Still, they might be useful to confirm a protein-based ELISA.

Recombinantly expressed CARLO-1 provided an indirect ELISA with high sensitivity, specificity, and selectivity. Interestingly, proteins FadL and CARLO-1 were identified in the 2D-gel of the OM fraction, but not from SCP, where only OmpA was identified, which was not recognized in immunoblot after recombinant expression in E. coli. Thus, outer membrane protein extracts might be beneficial to identify surface immunogens.

Previous studies identified outer membrane protein P6 [16] and RTX exoproteins, especially PnxIIIA [17, 18], as immunogens in $R$. pneumotropicus Mice intranasally vaccinated with modified recombinant PnxIIIA were protected against $R$. pneumotropicus infections [18] and might thus also be an interesting target for serodiagnosis. However, we recently showed that $18 \%$ of the tested $R$. pneumotropicus isolates and $88 \%$ of $R$. heylii isolates lack the pnxIII gene [4], whereas the carlo1 gene was present in all 21 analyzed strains of $R$. pneumotropicus and $R$. heylii. Although protein expression and posttranslational modifications were not studied, its presence on the gene level is an important prerequisite for the consistent identification of various Rodentibacter strains. By sequencing and in silico analysis of $R$. pneumotropicus and $R$. heylii, Sasaki et al. predicted four genes encoding for YadA-like proteins that were not further characterized [25]. These proteins are often associated with functions in transport, adhesion, and agglutination [26]. The C-terminal sequence of CARLO-1 (residues 238-316) is homologous to the YadA-anchor domain, although the alignment with the $\mathrm{N}$-terminal sequence was not related to any of the sequences reported by Sasaki et al. (data not shown). In silico analysis using the programs PSORTb [27] and LipoP [28] predicted that CARLO-1 is located in the outer membrane, which is supported by its identification in the SLS-insoluble membrane fraction.

\section{Conclusion}

Four ELISA based on various immunogenic components of $R$. pneumotropicus were established that specifically detected antibodies in sera of $\mathrm{C} 57 \mathrm{BL} / 6$ and $\mathrm{BALB} / \mathrm{C}$ mice experimentally infected with $R$. pneumotropicus. The newly identified and recombinantly expressed protein CARLO-1 appeared to be very promising in terms of sensitivity, specificity, and selectivity for the serological detection of $R$. pneumotropicus and $R$. heylii infections. Interestingly, an ELISA based on whole-cell antigen preparation selectively detected infections with $R$. pneumotropicus without cross-reactivity to sera obtained from mice infected with $R$. heylii. Thus, the Strep-rCARLO-1-His-E LISA may be used in routine health monitoring to screen for Rodentibacter infections while differentiation may be possible by the WCA-based ELISA.

\section{Methods}

Reagents were obtained from the following manufacturers: Applichem (Darmstadt, Germany): Ethylenediaminetetraacetic acid (EDTA), iodoacetamide, Proteinase K, Tris (hydroxymethyl) aminomethane (Tris base); Bio-Rad Laboratories $\mathrm{GmbH}$ (Munich, Germany): Bio-Lyte 3-10 buffer, mineral oil, Oriole ${ }^{\mathrm{Tm}}$ fluorescent gel stain, Precision Plus Protein ${ }^{\mathrm{TM}}$ protein standard (unstained and dual color), Precision protein StrepTactin-HRP conjugate (\#350000206), TransBlot Turbo RTA Transfer Kit LF PVDF Mini; Biosolve BV (Valkenswaard, Netherlands): Acetonitrile (HPLC gradient grade) and formic acid ( $\geq 99 \%$ ); Biozym Scientific GmbH (Hessisch Oldendorf, Germany): Advansta blocking buffer, Advansta washing buffer, isopropyl $\beta$-D-1-thiogalactopyranoside (IPTG) and WesternBright $^{\mathrm{Tm}}$ Sirius substrate solution; Carl Roth GmbH (Karlsruhe, Germany): 1,4-Dithiothreitol (DTT, $\geq 99 \%$ ), Ampicillin, glycerol (99.5\%), brain heart infusion (BHI) broth, hydrochloric acid (37\%), lysogeny broth (LB) medium, phenol, phosphate-buffered saline pH 7.4 (PBS), PBS with Tween 20 (PBS-T, pH 7.4), sodium dodecyl sulfate (SDS, $\geq 99.5 \%$ ), and urea ( $\geq 99.5 \%)$; Charles River Laboratories (Sulzfeld, Germany): specific-pathogen-free $\mathrm{BALB} / \mathrm{c}$ mice used for experimental infection; Elocin-lab GmbH (Oberhausen, Germany): horse serum; GE Healthcare (Fairfield, CT, USA): HisTrap ${ }^{\text {тм }}$ HP $(1 \mathrm{~mL})$; Honeywell Specialty Chemicals Seelze GmbH (Seelze, Germany): bromophenol blue; Jackson ImmunoResearch Laboratories, Inc. (West Grove, PA, USA): Peroxidase-conjugated AffiniPure goat anti-mouse IgG + IgM $(\mathrm{H}+\mathrm{L}$, specific-pathogen-free SPF C57BL/6 mice used for experimental infection; Merck KGaA (Darmstadt, Germany): pET21b vector; NH DyeAGNOSTICS GmbH (Halle, Germany): Immuno Blue HRP Substrate; Oxoid Deutschland $\mathrm{GmbH}$ (Wesel, Germany): Columbia agar with sheep blood plus (CBA); Peqlab Biotechnologie $\mathrm{GmbH}$ (Erlangen, Germany): agarose (peqGold); Roche Diagnostics International AG (Rotkreuz, Switzerland): DNase I (RNase-free); Serva Electrophoresis GmbH (Heidelberg, Germany): Acrylamide/bis(acrylamide) (30\% T, 2.67\% C), Albumin bovine (Fraction V, protease-free), CHAPS, TEMED, ammonium persulfate (99\%), Coomassie Brilliant Blue G250, glycine (>98.5\%), protease inhibitor mix B and trypsin (sequencing grade, MS approved); 
Sigma-Aldrich GmbH (Taufkirchen, Germany): 2-mercaptoethanol (BioUltra), ammonium bicarbonate $(\geq 99.5 \%)$ carbonate-bicarbonate buffer, imidazole $(\geq 99.5 \%)$, magnesium chloride hexahydrate $\left(\mathrm{MgCl}_{2}\right.$, $\geq 99 \%$ ), low-melting agarose, sodium hydroxide, sodium $N$-laurylsarcosinate, thiourea $(\geq 99 \%)$ and $\operatorname{Triton}^{\text {Tw }} \mathrm{X}-100$; SurModics Inc. (Eden Prairie, Minnesota, USA): StabilZyme Select ${ }^{\circ}$, Assay Diluent (Protein-free); Thermo Fisher Scientific (Waltham, Massachusetts, USA): Albumin standard $(2 \mathrm{mg} / \mathrm{mL})$, SuperBlock ${ }^{\circ}$ (PBS), 6x-His Epitope Tag Antibody (HIS.H8); Seramun Diagnostika GmbH (Heidesee, Germany): TMB substrate solution.

Water was produced in-house using a Purelab Ultra water purification system (resistance $>18.2 \mathrm{M} \Omega \cdot \mathrm{cm}$; total organic content $<5$ ppb; ELGA LabWater GmbH, Celle, Germany).

\section{Bacterial strains and culture media}

$R$. pneumotropicus strain JF4Ni and $R$. heylii strain SF27GVG were isolated from German research facilities. $R$. pneumotropicus strain ATCC35149 was purchased from ATCC (Manassas, VA, USA). All others strains were kindly provided by Laurentiu Benga (HeinrichHeine-University, Düsseldorf, Germany). R. pneumotropicus and $R$. heylii strains were cultivated overnight at $37^{\circ} \mathrm{C}$ on CBA and then transferred to BHI broth supplemented with $10 \%(v / v)$ inactivated and sterile-filtrated horse serum for $R$. heylii strains.

\section{Serum samples}

Sera were obtained from mice experimentally infected with $R$. pneumotropicus [4]. Briefly, specific-pathogen-free (SPF) eight week old female BALB/c $(n=16)$ and C57BL/ 6 mice $(n=16)$ were intranasally infected with $R$. pneumotropicus strain JF4Ni using a bacterial load of $10^{8} \mathrm{CFU}$. At $28 \mathrm{dpi}$, mice were anaesthetized through intraperitoneal application of $100 \mathrm{mg}$ ketamine per $\mathrm{kg}$ body weight and 5 mg xylazine per kg body weight, blood was collected by cardiac puncture and the mice finally killed by cervical dislocation. Positive sera of $R$. heylii, Streptobacillus (S.) moniliformis, and Mycoplasma (M.) pulmonis were also obtained from experimental infections ([29] and manuscripts in preparation). Field sera obtained from German animal facilities and tested for different pathogens as recommended by FELASA were provided by GVG Diagnostics including the test results.

\section{PCR and sequencing}

Genomic DNA was isolated from cell pellets of Rodentibacter strains using the DNeasy Blood \& Tissue Kit and the Rodentibacter species identified by PCR [11]. The sequences of ompA, fadL, and carlo1 genes were amplified from a mixture of purified genomic DNA $(5 \mu \mathrm{L})$ as well as forward and reverse primer $(2.5 \mu \mathrm{L}$ each, $10 \mathrm{pmol} / \mathrm{L}$,
Eurofins Genomics GmbH, Ebersberg, Table 3), Phusion HF Buffer $(10 \mu \mathrm{L}$, New England Biolabs Inc., Ipswich, MA, USA), dNTPs $(1 \mu \mathrm{L}, 0.1 \mathrm{~mol} / \mathrm{L})$, PCR-grade water $(28.5 \mu \mathrm{L})$, and Phusion High-Fidelity DNA Polymerase $(0.5 \mu \mathrm{L}$, New England Biolabs Inc.). Amplification was performed on a Mastercycler Nexus (Eppendorf) using an initial denaturation at $95^{\circ} \mathrm{C}$ for 2 min followed by 30 cycles $\left(95^{\circ} \mathrm{C}\right.$ for $2 \mathrm{~min}, 55^{\circ} \mathrm{C}$ for $30 \mathrm{~s}$, and $72^{\circ} \mathrm{C}$ for $\left.55 \mathrm{~s}\right)$ and a final extension $\left(72^{\circ} \mathrm{C}\right.$ for $\left.10 \mathrm{~min}\right)$. Samples were stored at $4{ }^{\circ} \mathrm{C}$.

An aliquot of the PCR product $(5 \mu \mathrm{L})$ was mixed with DNA Loading Dye $(1 \mu \mathrm{L}$, Thermo Scientific) and separated on a $1 \%$ agarose gel $(120 \mathrm{~V}, 30 \mathrm{~min})$. A GeneRuler 100 bp Plus DNA Ladder (Thermo Scientific) was loaded as standard. The gel image was obtained by UV transillumination. For sequencing, PCR products were purified with the NucleoSpin Gel and PCR Clean-up Kit (Macherey-Nagel, Düren, Germany) according to the manufacturer's instructions. Briefly, purified PCR product $(5 \mu \mathrm{L}, 20-80 \mathrm{ng} / \mu \mathrm{L})$ were mixed with the forward and reverse primers for carlo- $1 \quad(5 \mathrm{pmol} / \mu \mathrm{L})$ and sequenced at GATC Biotech (Konstanz, Germany).

\section{WCA preparation}

The WCA was prepared using a previously reported protocol [29]. Briefly, a cell pellet of $R$. pneumotropicus was suspended in B-Per Bacterial Extraction Reagent $(4 \mathrm{~mL}$ per $g$ pellet, Thermo Scientific), sonicated, and the supernatant dialyzed (8 kDa MW cut-off) against PBS.

\section{OM preparation}

OM proteins were prepared by sarcosine differential solubility [30]. Briefly, an overnight cell culture $(0.5 \mathrm{~L})$

Table 3 Sequences of forward $(\mathrm{fd})$ and reverse primers (rev) used to amplify ompA, fadL, and carlol genes

\begin{tabular}{|c|c|c|c|}
\hline $\begin{array}{l}\text { Target } \\
\text { gene }\end{array}$ & NCBI accession & Primer & Sequence $\left(5^{\prime}-3\right)^{a}$ \\
\hline \multirow[t]{2}{*}{$\overline{o m p A}$} & WP_018357032.1 & OmpA_fd & $\begin{array}{l}\text { GAT CAG CCC GGG AAA } \\
\text { AAA ACT GCA ATC GCA } \\
\pi\end{array}$ \\
\hline & & OmpA_rev & $\begin{array}{l}\text { GAT CAG CTC GAG TाT } \\
\text { AGA ACC ATT AAC TGC } \\
\text { GA }\end{array}$ \\
\hline \multirow[t]{2}{*}{ fadl } & WP_018355328.1 & FadL_fd & $\begin{array}{l}\text { GAT CAG CCC GGG AAA } \\
\text { AAA TIT AAT CAA TCT } \\
\pi\end{array}$ \\
\hline & & FadL_rev & $\begin{array}{l}\text { GAT CAG CTC GAG TTA } \\
\text { GAA ACG ATA ATT TAC } \\
\text { AT }\end{array}$ \\
\hline \multirow[t]{2}{*}{ carlo1 } & WP_018356225.1 & CARLO-1_fd & $\begin{array}{l}\text { GAT CAG CCC GGG ACA } \\
\text { TTG TCA TTA GCC TTA CTT G }\end{array}$ \\
\hline & & CARLO-1_rev & $\begin{array}{l}\text { GAT CAG CTC GAG GCC } \\
\text { AGC ATT ATA GCT AAC AC }\end{array}$ \\
\hline
\end{tabular}

anderlined restriction sites of Xmal (CCC GGG) and Xhol (CTCGAG) were used for cloning of amplifications products into pET21b_JF 
was centrifuged $\left(5000 \times \mathrm{g}, 4{ }^{\circ} \mathrm{C}, 20 \mathrm{~min}\right)$, the cell pellet suspended in Tris- $\mathrm{HCl}(0.2 \mathrm{~mol} / \mathrm{L})$ containing EDTA (10 mmol/L, pH 7.8), and disrupted by three freeze/thaw cycles in liquid nitrogen followed by six cycles of sonication ( $30 \mathrm{~s} /$ cycle, pulse: $1 \mathrm{~s}$, pause: $1 \mathrm{~s}, 30 \%$ amplitude, Vibra-Cell 75,041 with a SM0303 [Sonics \& Materials Inc., Newtown, CT, USA]). Protease Inhibitor Mix B $(150 \mu \mathrm{L})$ was added and the sample centrifuged at 5000 x $g\left(10 \mathrm{~min}, 4^{\circ} \mathrm{C}\right)$. The supernatant was centrifuged at $100,000 \times g\left(1 \mathrm{~h}, 4^{\circ} \mathrm{C}\right)$. The obtained pellet was washed with Tris- $\mathrm{HCl}(10 \mathrm{mmol} / \mathrm{L})$ containing EDTA $(10 \mathrm{mmol} /$ L, pH 7.8; buffer A), suspended in buffer A containing SLS $(0.5 \%, v / v)$, incubated $(1 \mathrm{~h}, \mathrm{RT})$, and centrifuged $\left(100,000 \times g, 1 \mathrm{~h}, 4^{\circ} \mathrm{C}\right)$. The supernatant contained the IM proteins. The pellet was washed once with buffer $\mathrm{A}$ and suspended in buffer A (overnight, $4{ }^{\circ} \mathrm{C}$ ) to give the $\mathrm{OM}$ fraction. Aliquots were stored at $-80^{\circ} \mathrm{C}$. The protein concentration was determined by micro-Bradford assay.

\section{Protein digestion}

Proteinase K (2 mg) was added to WCA or OM protein solutions $(250 \mu \mathrm{L})$ and incubated on an orbital shaker (600 rpm, overnight, $56^{\circ} \mathrm{C}$ ).

\section{LPS preparation}

A cell pellet of $R$. pneumotropicus (140 mg) was suspended in PBS $(2 \mathrm{~mL})$, heated $\left(95^{\circ} \mathrm{C}, 10 \mathrm{~min}, 600 \mathrm{rpm}\right)$, and sonicated $(3 \times 30 \mathrm{~s}$, pulse: $1 \mathrm{~s}$, pause: $1 \mathrm{~s}$, amplitude: $40 \%$, Sonopuls HD2200, MS73 tip [Bandelin]). $\mathrm{MgCl}_{2}$ (final $3 \mathrm{mmol} / \mathrm{L}$ ) and a spatula tip DNase I were added and the solution incubated $\left(30 \mathrm{~min}, 37^{\circ} \mathrm{C}\right)$. Proteinase $\mathrm{K}$ (spatula tip) was added and incubated $\left(600 \mathrm{rpm}, 56^{\circ} \mathrm{C}\right.$, overnight). Tris-saturated phenol ( $2 \mathrm{~mL}, \mathrm{pH} 8.0)$ was added, mixed, incubated on an orbital shaker $(500 \mathrm{rpm}$, $65^{\circ} \mathrm{C}, 15 \mathrm{~min}$ ), and centrifuged (5000 x $\mathrm{g}, 10 \mathrm{~min}, \mathrm{RT}$ ). The upper phase was transferred to a fresh tube and the lower phase was extracted with water $(2 \mathrm{~mL})$ and treated as described. After centrifugation, both upper phases were combined and the sample was dialyzed against highly pure water using a Membra-Cel dialysis membrane $(3.5 \mathrm{kDa}$ cut-off, $16 \mathrm{~mm}$ diameter, Serva Electrophoresis $\mathrm{GmbH}$ ) until the absorbance of the dialysis water recorded at $260 \mathrm{~nm}$ was zero.

\section{Molecular cloning and protein expression}

PCR products were cloned into pET21b-JF (Additional file 12), which is a pET21b plasmid variant containing additional DNA sequence encoding an $\mathrm{N}$-terminal Strep-tag II. Introduced restriction sites for $X m a I$ and $X h o I$ were used for cloning of amplification products using primers outlined in Table 3 resulting in expression of recombinant proteins with an $\mathrm{N}$-terminal Strep-tag and a C-terminal His-tag. Plasmids were transformed to $E$. coli BL21 by electroporation. LB-medium $(0.5 \mathrm{~L})$ was inoculated with an overnight culture and bacteria were grown at $37^{\circ} \mathrm{C}$ with continuous shaking until an optical density at $600 \mathrm{~nm}$ of 0.6 was obtained. Protein expression was induced by addition of IPTG $(1 \mathrm{mmol} / \mathrm{L})$. After $4 \mathrm{~h}$, the culture was centrifuged $\left(7000 \times \mathrm{g}, 15 \mathrm{~min}, 4^{\circ} \mathrm{C}\right)$ and the cell pellet was stored at $-20^{\circ} \mathrm{C}$. Proteins were solubilized and purified as described [31]. Fractions containing the target protein were dialyzed against $8 \mathrm{~mol} / \mathrm{L}$ urea in PBS, pH 7.4 $(10 \mathrm{kDa}$ MW cut-off) and stored at $-80^{\circ} \mathrm{C}$. Protein concentrations were determined on a NanoDrop 2000c spectrophotometer (Thermo Fisher Scientific, USA) against dialysis buffer as blank.

\section{Micro-Bradford assay}

Protein concentrations of whole-cell extracts and OM preparations were determined by a micro-Bradford assay [32]. Briefly, protein solution $(5 \mu \mathrm{L}$, duplicates) were mixed with Coomassie Brilliant Blue G-250 solution $(250 \mu \mathrm{L}, 0.1 \mathrm{~g} / \mathrm{L}$ in $10 \%$ phosphoric acid and $5 \%$ aqueous ethanol) in a 96-well microtiter plate and the absorbance was recorded at $595 \mathrm{~nm}$ on a SpectraMax Paradigm microtiter plate reader (Molecular Devices, San José, CA, USA). Three two-fold dilution series of bovine serum albumin $(1.0 \mathrm{~g} / \mathrm{L}$ to $62.5 \mu \mathrm{g} / \mathrm{mL})$ were used as reference standard.

\section{SDS-page}

SDS-PAGE was performed as described [31]. Proteins were stained using colloidal Coomassie Brilliant Blue (CBB) G-250 [33] or Oriole ${ }^{\text {tw }}$ fluorescent stain $\left(\lambda_{\text {exc }}=270\right.$ $\left.\mathrm{nm}, \quad \lambda_{\mathrm{em}}=604 \mathrm{~nm}\right)$ according to the manufacturer's protocol. LPS was stained with the Pro-Q Emerald 300 Glycoprotein Gel and Blot Kit according to the manufacturer's instructions. Images were taken on a ChemiDoc MP CCD camera system (Bio-Rad Laboratories).

\section{2-DE}

For 2-DE, $300 \mathrm{mg}$ bacterial pellet were washed twice with $100 \mathrm{mM}$ sucrose $(w / v)$ and then lysed in $1 \mathrm{~mL} 2 \%$ SDS $(w / v), 10 \%$ glycerol $(v / v), 30 \mathrm{mmol} / \mathrm{L}$ Tris $(w / v), \mathrm{pH}$ 6.8 for $5 \mathrm{~min}$ at $95^{\circ} \mathrm{C}$ and $500 \mathrm{rpm}$. After incubation in an ultrasonic bath ( $5 \mathrm{~min}, \mathrm{RT}$ ), the SCP was centrifuged at $10,000 \times g(5 \mathrm{~min}, \mathrm{RT})$ and the protein concentration of the supernatant was determined by micro-Bradford assay. Proteins were labeled using the Smart Protein Layers Kit and T-Rex Protein Labeling Kit (NH DyeAGNOSTICS GmbH, Halle, Germany) using the manufacturer's instructions with slight modifications. The $\mathrm{pH}$ of the $\mathrm{OM}$ was adjusted to 8.0 with $0.1 \mathrm{~mol} / \mathrm{L}$ sodium hydroxide and samples were diluted with SPL reaction buffer (provided with the kit) to obtain a final protein concentration of $0.5 \mu \mathrm{g} / \mu \mathrm{L}$. T-Rex dye $(0.5 \mu \mathrm{L})$ and SPL 
Smartanalyzer SMA basic blue (S) $(0.5 \mu \mathrm{L})$ were added to the protein sample $(10 \mu \mathrm{g})$ and incubated for $25 \mathrm{~min}$ on ice. After the incubation, the labeled sample was further diluted with 2D-sample buffer $(7 \mathrm{~mol} / \mathrm{L}$ urea, $2 \mathrm{~mol} /$ L thiourea, 4\% CHAPS, $60 \mathrm{mmol} / \mathrm{L} \mathrm{DTT)}$ to obtain a final protein concentration of $0.4 \mu \mathrm{g} / \mu \mathrm{L}$.

IPG strips $(7 \mathrm{~cm}, 3-10$ non-linear Strips [Serva]) were passively rehydrated gel-side down in $125 \mu \mathrm{L}$ rehydration buffer $(2 \mathrm{~mol} / \mathrm{L}$ thiourea, $7 \mathrm{~mol} / \mathrm{L}$ urea, $4 \% \quad[w / v]$ CHAPS, $30 \mathrm{mmol} / \mathrm{L}$ DTT, $0.5 \%$ Bio-Lyte 3-10 buffer, $0.0005 \%$ bromophenol blue $[v / w])$ for $6 \mathrm{~h}$ at RT. Strips were placed gel-side up in a cup loading focusing tray. For each IPG strip two electrode wicks were soaked with rehydration buffer $(20 \mu \mathrm{L})$ and placed at the ends of the strip. The sample cup was placed at the anode and the labeled sample added ( $50 \mu \mathrm{L}, 20 \mu \mathrm{g}$ protein). IPG strip and cup were covered with $4 \mathrm{~mL}$ mineral oil and transferred to a Protean IEF cell (Bio-Rad Laboratories). Focusing was done at $20^{\circ} \mathrm{C}$ using a voltage gradient to $150 \mathrm{~V}$ within $1 \mathrm{~h}$ (current limited to $50 \mu \mathrm{A}$ per strip) and increasing further to $300 \mathrm{~V}$ and $1000 \mathrm{~V}$ within one hour each, and finally to $3000 \mathrm{~V}$ within 2 h. The high voltage remained until 12,000 Vh were reached in total. Strips were equilibrated in equilibration buffer $(2.5 \mathrm{~mL} ; 6 \mathrm{~mol} / \mathrm{L}$ urea, 2\% SDS, $20 \%$ glycerol, $\quad 50 \mathrm{mmol} / \mathrm{L}$ Tris- $\mathrm{HCl}, \quad \mathrm{pH} 8.8)$ containing DTT $(1 \%, w / v)$ on an orbital shaker $(300 \mathrm{rpm})$. After $15 \mathrm{~min}$ (RT), equilibration buffer $(2.5 \mathrm{~mL})$ containing iodoacetamide $(2.5 \%, w / v)$ was added. After a 15 -min incubation (300 rpm, RT), strips were immersed in running buffer, placed on top of a polyacrylamide gel ( $\mathrm{T}=13.5 \%, \mathrm{C}=2.67 \%)$, and fixed with low-melting agarose $(0.5 \%, w / v)$ in Tris-buffer $(25 \mathrm{mmol} / \mathrm{L}$ Tris-HCL, $192 \mathrm{mmol} / \mathrm{L}$ glycine, pH 8.3, $0.1 \%(w / v)$ SDS) containing $0.001 \%$ bromophenol blue.

\section{Immunoblot}

Proteins were electroblotted onto a low-fluorescent PVDF membrane using a Trans-Blot Turbo transfer cell and the RTA transfer kit (Bio-Rad Laboratories) for 10 $\min (25 \mathrm{~V}, 1.3 \mathrm{~A}, \mathrm{RT})$ and processed as described [31]. For detection, the membrane was incubated with Immuno Blue HRP-Substrate (NH DyeAGNOSTICS, Halle, Germany) for 10 min or with WesternBright Sirius HRP-Substrate (Advansta, Menlo Park, CA, USA) for 2 min, washed in Advan washing solution, and the fluorescence or chemoluminescence recorded (ChemiDoc MP CCD camera system, Bio-Rad Laboratories).

\section{Enzyme-linked immunosorbent assay (ELISA)}

Sera were tested using the Mouse Pasteurella pneumotropica ELISA Kit (XpressBio, Frederick, MD, USA) according to the manufacturer's instructions. The absorbance was recorded at $405 \mathrm{~nm}$ (Infinite F50 absorbance microplate reader, Tecan, Männedorf, Switzerland) for each well and the absorbance recorded for control wells subtracted (absorbance difference).

Alternatively, Medium Bind microplates (Brand, Wertheim, Germany; 96-well, U-shape) were coated with $400 \mathrm{ng}$ whole-cell antigen in carbonate-bicarbonate buffer $(50 \mathrm{mmol} / \mathrm{L}, \mathrm{pH} 9.6)$ for $45 \mathrm{~min}$ at $37^{\circ} \mathrm{C}$. OM- and LPS-ELISA were prepared by coating OM extract $(0.4 \mu \mathrm{g})$ and LPS preparation $(0.5 \mu \mathrm{L})$ in PBS $(0.1 \mathrm{~mL}, \mathrm{pH} 7.4)$ overnight at $4{ }^{\circ} \mathrm{C}$. A solution of Strep-rCARLO-1-His $(0.1 \mu \mathrm{g}, 5 \mu \mathrm{L})$ in PBS (pH 7.4) containing urea $(8 \mathrm{~mol} / \mathrm{L}))$ were mixed with PBS $(95 \mu \mathrm{L})$ in the well and coated overnight $\left(4{ }^{\circ} \mathrm{C}\right)$. Wells were washed three times (PBS, $\left.300 \mu \mathrm{L}\right)$ using a Columbus Pro ELISA washer (Tecan), blocked with Superblock $(300 \mu \mathrm{L}, 30 \mathrm{~min}, \mathrm{RT})$, and stored at $4{ }^{\circ} \mathrm{C}$. During all incubations, plates were covered with adhesive foil (SealPlate, Excel Scientific, CA, USA). Wells were incubated with diluted murine serum (1:50 in Assay Diluent; $100 \mu \mathrm{L}, \mathrm{RT})$. After $45 \mathrm{~min}$, the wells were washed three times with PBS-T $(300 \mu \mathrm{L} /$ well $)$ and conjugate solution was added $(100 \mu \mathrm{L} /$ well, goat anti-mouse-HRP, 1:30,000 in Stabilzyme Select, $30 \mathrm{~min}, \mathrm{RT})$. Wells were washed and TMB added ( $100 \mu \mathrm{L}, 15 \mathrm{~min}, \mathrm{RT})$. Finally, the reaction was stopped with sulfuric acid $(100 \mu \mathrm{L}$ per well, $0.5 \mathrm{~mol} / \mathrm{L})$ and the absorbance recorded at $450 \mathrm{~nm}$.

\section{In-gel digestion and NanoRP-HPLC-ESI-QTOF-MS/MS}

Gel bands and spots in CBB G-250-stained gels were digested and peptides processed as described [31]. Data were analyzed with the Progenesis QI search engine using the following parameters: database NCBI "Pasteurella pneumotropica" (21,931 sequences, downloaded 22.09.2017), precursor and product MHP window (singly protonated peptide mass of the theoretical sequence) was -1 , "number by match for peptide minimum value" was 3 , "number peptide for protein minimum value" was 1 , "number by match for protein minimum value" was 7 , "protein mass maximum atomic mass unit value" was 250,000 , false positive rate value was 4 , one missed cleavage site, trypsin as "digester reagent", and methionine oxidation and cysteine carbamidomethylation as variable modifications. The final fragment peptide table generated by the ion accounting output was filtered for proteins from $R$. pneumotropicus and $R$. heylii. Proteins represented by at least three different peptides and identified by "AutoCurate" ( $>95 \%$ probability) were considered confident.

\section{ELISA validation and statistical analysis}

The limit of detection (LOD) was calculated from the mean absorbance value of sera from uninfected SPF mice plus three times its standard deviation (SD). Diagnostic sensitivity (DSn), diagnostic specificity (DSp), and selectivity were calculated using the 
following equations: $\mathrm{DSn}=[\mathrm{TP} /(\mathrm{TP}+\mathrm{FN})] \times 100$; $\mathrm{DSp}=[\mathrm{TN} /(\mathrm{TN}+\mathrm{FP})] \quad \times 100 ; \quad$ Selectivity $=\left[\mathrm{TN}_{\mathrm{F}} /\right.$ $\left.\left(\mathrm{TN}_{\mathrm{F}}+\mathrm{FP}_{\mathrm{F}}\right)\right] \times 100$; with $\mathrm{TP}$ : true positives, $\mathrm{TN}$ : true negatives, FP: false positives, FN: false negatives, and F: sera positive for other FELASA-listed pathogens. Repeatability of the indirect ELISA was tested by 42 replicates of positive (PC, anti-His antibody, 1:4000 in StabilZyme Select) and negative controls each (NC, $R$. pneumotropicus [-] serum pool, 1:50 in Assay Diluent). Intermediate precision was tested by five replicates of $\mathrm{PC}$ and $\mathrm{NC}$ each on five different plates. Calculations followed ISO 5725-2 [34].

\section{Software}

Graph Pad Prism 7.0 (Graph Pad Software, La Jolla, CA, USA) was used for graphical representations and statistical analysis. Linear regression of standard curves of micro-Bradford assays were calculated with Microsoft Excel 2013 (Microsoft, Albuquerque, NM, USA). Spot matching of 2D-gels and 2D-immunoblots was done using Delta2D v4.6 (Decodon GmbH, Greifswald, Germany). Sequencing results were analyzed with DNA Baser v4.36 (Heracle BioSoft, Arges, Romania) and alignment was performed using BLASTn v2.8 [35].

\section{Additional files}

Additional file 1: Proteins identified from the OM fraction in Fig. 3a by tandem MS. Given are the gel segment, protein accession number at $\mathrm{NCBl}$, protein description, protein score, average mass (Da), number of protein-matched products, number of protein-matched peptides, number of digested peptides and sequence coverage (\%). (XLSX $11 \mathrm{~kb}$ )

Additional file 2: Proteins identified from 2-DE of SCP and OM fraction and verification of Strep-rCARLO-1-His expression by tandem MS. Given are the sample, database, protein accession number at NCBI, protein description, protein score, average mass (Da), sequence coverage (\%), number of protein-matched peptides and the peptide sequences. (XLSX $12 \mathrm{~kb})$

Additional file 3: SDS-PAGE (A) and immunoblots (B) of different preparations obtained during expression of Strep-rFadL-His in E. coli. The following samples were loaded: cell extract of $E$. coli before inducing protein expression (1) and bacterial pellets after $1 \mathrm{~h}, 2 \mathrm{~h}$ and $3 \mathrm{~h} \mathrm{(2-4),}$ and cytoplasm (5) and inclusion bodies (6) prepared from cells $3 \mathrm{~h}$ after the expression was induced by IPTG. 7: SLS-insoluble membrane fraction. Proteins were stained with colloidal CBB G-250. M denotes marker proteins with the molecular masses in $\mathrm{kDa}$ indicated left. Immunoblots probed with anti-Strep-Tactin-HRP conjugate and sera obtained from C57BL/6 and BALB/C mice experimentally infected with $R$. pneumotropicus or uninfected (control). Arrow indicates the band corresponding to Strep-rFadL-His and selected for confirmation by tandem mass spectrometry. (TIF $354 \mathrm{~kb}$ )

Additional file 4: SDS-PAGE (A) and immunoblots (B) of different preparations obtained during expression of Strep-rOmpA-His in E. coli. The following samples were loaded: cell extract of $E$. coli before inducing protein expression (1) and bacterial pellets after $1 \mathrm{~h}, 2 \mathrm{~h}$ and $4 \mathrm{~h}(2-4)$, and cytoplasm (5) and inclusion bodies (6) prepared from cells $3 \mathrm{~h}$ after the expression was induced by IPTG. Proteins were stained with colloidal CBB G-250. M denotes marker proteins with the molecular masses in kDa indicated left. Immunoblots probed with anti-His mAb and sera obtained from C57BL/6 and BALB/C mice experimentally infected with $R$. pneumotropicus or uninfected (control). Arrow indicates the band corresponding to Strep-rFadL-His and selected for confirmation by tandem mass spectrometry. (TIF 324 kb)

Additional file 5: SDS-PAGE (A) and immunoblots (B) of different preparations obtained during expression of Strep-rHP-His in E. coli. The following samples were loaded: cell extract of $E$. coli before inducing protein expression (1) and bacterial pellets after $1 \mathrm{~h}, 2 \mathrm{~h}$ and $4 \mathrm{~h}$ (2-4), and cytoplasm (5) and inclusion bodies (6) prepared from cells $3 \mathrm{~h}$ after the expression was induced by IPTG. 7: SLS-insoluble membrane fraction. Proteins were stained with colloidal CBB G-250. Proteins were stained with colloidal CBB G-250. M denotes marker proteins with the molecular masses in $\mathrm{kDa}$ indicated left. Immunoblots probed with anti-His mAb and sera obtained from C57BL/6 and BALB/C mice experimentally infected with R. pneumotropicus or uninfected (control). Arrow indicates the band corresponding to Strep-rHP-His and selected for confirmation by tandem mass spectrometry. (TIF $340 \mathrm{~kb}$ )

Additional file 6: SDS-PAGE stained with colloidal CBB G-250 (A) and immunoblot probed with anti-Strep-Tactin-HRP conjugate (B) of solubilized Strep-rHP-His from different preparations and fractions. The following samples were loaded: cytoplasm (C), fractions 1 to 6 (S1-S6) obtained during stepwise solubilization of Strep-rHP-His inclusion bodies. $\mathrm{M}$ denotes marker proteins with the molecular masses indicated left. (TIF 196 kb)

Additional file 7: Purification of Strep-rHP-His. SDS-PAGE of recombinantly expressed Strep-rHP-His stained with colloidal Coomassie. $\mathrm{M}$ denotes marker proteins with the molecular masses indicated left. (TIF $42 \mathrm{~kb}$ )

Additional file 8: Results of Rodentibacter identification in field mice. Given are the animal number, the cultivation results based on the characteristics of Gram, oxidase, and morphology, the MALDI-ToF results from corresponding spots of Pasteurellaceae, the PCR result of corresponding spots of Pasteurellaceae, and the results of the Strep-rCARLO-1His and the commercial Pasteurella pneumotropica ELISA, respectively. (XLSX $9 \mathrm{~kb}$ )

Additional file 9: Commercial Pasteurella pneumotropica ELISA results of sera obtained from a unit of a German animal facility infected with $R$. pneumotropicus. Test specific cut-off value (0.3) is indicated as a dashed line. (TIF $101 \mathrm{~kb}$ )

Additional file 10: Differentiation of Rodentibacter strains by PCR [11]. Isolates with a characteristic band at $451 \mathrm{bp}$ were identified as $R$. pneumotropicus (A), whereas isolates showing a band at $326 \mathrm{bp}$ were identified as $R$. heylii (B). Control: No DNA was added to the PCR reaction. (TIF 239 kb)

Additional file 11: HP-screening in murine isolates of $R$. pneumotropicus (A) and R. heylii (B) by PCR. Control [-]: No template was added to the $\mathrm{PCR}$ reaction. $100 \mathrm{bp}$ molecular marker is indicated left. (TIF $165 \mathrm{~kb}$ )

Additional file 12: Sequence of pET21b_JF (5406 bp). Nucleotide sequence of vector pET21b_JF encoding Strep-tag II and restrictions sites $X \mathrm{mal}$ and Xhol. (PDF $116 \mathrm{~kb}$ )

\section{Abbreviations}

2-DE: two-dimensional gel electrophoresis; CARLO-1: Characteristic antigen for Rodentibacter of laboratory origin 1; CoV: Coefficient of variation; Cyt: Cytosolic fraction; dpi: Days post infection; DSn: Diagnostic sensitivity; DSp: Diagnostic specificity; E. coli: Escherichia coli; ELISA: Enzyme-linked immunosorbent assay; ESI: Electrospray ionization; FadL: Long-chain fatty acid transport protein; FELASA: Federation of Laboratory Animal Science Associations; HP: Hypothetical protein; IM: SLS-soluble membrane fraction; IMAC: Immobilized metal ion affinity chromatography; LOD: Limit of detection; LPS: Lipopolysaccharides; MS: Mass spectrometry; MW: Molecular weight; NC: Negative control; OM: SLS-insoluble membrane fraction; OmpA: Outer-membrane protein A; P.: Pasteurella; PC: Positive control; PCR: Polymerase chain reaction; QTOF: Quadrupole time-of-flight; R.: Rodentibacter; RP-HPLC: Reversed-phase high performance liquid chromatography; RTX: Repeats-in-toxin; S. mon.: Streptobacillus moniliformis: SCP: SDS-lysed cell pellet; SDS-PAGE: Sodium dodecyl sulfate polyacrylamide gel electrophoresis; SLS: Sodium N-laurylsarcosinate; SPF: Specific-pathogenfree; WCA: Whole-cell antigen 


\section{Acknowledgments}

We thank Laurentiu Benga for providing Rodentibacter strains. Technical assistance of Tina Goldbach, Franziska Lange, Nadja Schlebe and Jessica Reisner is kindly acknowledged.

\section{Funding}

Financial support by the European Fund for Regional and Structure Development (EFRE, EU and Free State of Saxony) to RHo (project numbers 100209225 \& 100305277), CB (project numbers 100305285 \& 100211188), and GVG Diagnostics GmbH (project numbers 100208475 \& 100305269) as well as the Deutsche Forschungsgemeinschaft (INST 268/289-1) to RHo is gratefully acknowledged. We acknowledge support from the German Research Foundation (DFG) and Leipzig University within the program of Open Access Publishing.

The funding bodies had no role in study design, data collection and analysis, interpretation of data, decision to publish, or preparation of the manuscript.

\section{Availability of data and materials}

All data generated or analyzed during this study are included in this published article and its supplementary information files.

\section{Authors' contributions}

RHo and $\mathrm{CB}$ conceived the study. FF, DV, RHa, and RHo designed the experiments. Acquisition of data was mainly conducted by FF. Mass spectrometric analysis and two-dimensional gel electrophoresis were performed by DV. RHa and DV provided protocols. Infection studies and experiments on bacteriology and molecular biology were done by JF and SF. CB designed the experimental infections, bacteriologic and molecular biologic work. Data analysis was conducted by FF with support from DV, RHa and RHo. Manuscript was written by FF and RHo. All authors critically revised the manuscript, approved the final version and agreed to be accountable for all aspects of the work

\section{Ethics approval and consent to participate}

This animal study was registered and approved under no. TW 17/15 at the Provincial Head Office Saxony (Germany), Unit 24, Veterinary and Food Inspection (Landesdirektion Sachsen, Referat 24, Veterinärwesen und Lebensmittelüberwachung), which includes approval through the registered committee for animal experiments. This study and handling of mice in general was conducted in strict accordance with the principles outlined in the EU Directive 2010/63/EU and German Animal Protection Law.

\section{Consent for publication}

Not applicable.

\section{Competing interests}

GVG Diagnostics GmbH (Leipzig, Germany) is a provider of diagnostic services for laboratory animals. FF is a part-time employee of GVG Diagnostics.

\section{Publisher's Note}

Springer Nature remains neutral with regard to jurisdictional claims in published maps and institutional affiliations.

\footnotetext{
Author details

'Institute of Bioanalytical Chemistry, Faculty of Chemistry and Mineralogy, Universität Leipzig, Leipzig, Germany. ${ }^{2}$ GVG Diagnostics GmbH, Leipzig, Germany. ${ }^{3}$ Center for Biotechnology and Biomedicine, Universität Leipzig, Leipzig, Germany. ${ }^{4}$ Institute for Bacteriology and Mycology, Faculty of Veterinary Medicine, Universität Leipzig, Leipzig, Germany.

${ }^{5}$ Biotechnologisch-Biomedizinisches Zentrum, Universität Leipzig, Deutscher Platz 5, 04103 Leipzig, Germany.
}

Received: 9 August 2018 Accepted: 8 February 2019

Published online: 18 February 2019

\section{References}

1. Adhikary S, Nicklas W, Bisgaard M, Boot R, Kuhnert P, Waberschek T, et al. Rodentibacter gen. Nov. including R. pneumotropicus comb. nov., R. heylii sp. nov., $R$. myodis sp. nov., $R$. ratti $\mathrm{sp}$. nov., $R$. heidelbergensis sp. nov., $R$. trehalosifermentans sp. nov., $R$. rarus sp. nov., $R$. mrazii and two genomospecies. Int J Syst Evol Microbiol. 2017;67:1793-806.

2. Barthold SW, Stephen MG, Percy DH. Mouse. In: Pathology of laboratory rodents and rabbits. 4th ed: John Wiley \& Sons, Inc.; 2016. p. 1-118.

3. Kawamoto E, Sasaki H, Okiyama E, Kanai T. Pathogenicity of Pasteurella pneumotropica in Immunodeficient NOD/Shilic- scid/Jcl and Immunocompetent Crlj : CD1 (ICR) mice. Experimental animals. 2011:60(5):463-70.

4. Fornefett J, Krause J, Klose K, Fingas F, Hassert R, Benga L, et al. Comparative analysis of humoral immune responses and pathologies of $B A L B / C$ and C57BL/6 wildtype mice experimentally infected with a highly virulent Rodentibacter pneumotropicus (Pasteurella pneumotropica) strain. BMC Microbiol. 2018;18(45).

5. Scharmann W, Heller A. Survival and transmissibility of Pasteurella pneumotropica. Lab Anim. 2001;35(2):163-6.

6. Pritchett-Corning KR, Cosentino J, Clifford CB. Contemporary prevalence of infectious agents in laboratory mice and rats. Lab Anim. 2009;43(2):165-73.

7. Mähler M, Berard M, Feinstein R, Gallagher A, Illgen-Wilcke B, PritchettCorning $\mathrm{K}$, et al. FELASA recommendations for the health monitoring of mouse, rat, hamster, Guinea pig and rabbit colonies in breeding and experimental units. Lab Anim. 2014;48(3):178-92.

8. Miller M, Zorn J, Brielmeier M. High-resolution melting curve analysis for identification of pasteurellaceae species in experimental animal facilities. PLoS One. 2015;10(11):1-7.

9. Dole VS, Banu LA, Fister RD, Nicklas W, Henderson KS. Assessment of rpoB and 165 rRNA genes as targets for PCR-based identification of Pasteurella pneumotropica. Comp Med. 2010;60(6):427-35.

10. Hayashimoto N, Takakura A, Itoh T. Genetic diversity on 165 rDNA sequence and phylogenic tree analysis in Pasteurella pneumotropica strains isolated from laboratory animals. Curr Microbiol. 2005;51(4):239-43.

11. Benga L, Benten WPM, Engelhardt E, Bleich A, Gougoula C, Sager M. Development of a multiplex PCR assay based on the 16S-23S rRNA internal transcribed spacer for the detection and identification of rodent Pasteurellaceae. J Microbiol Methods. 2013;95:256-61.

12. Wullenweber-Schmidt M, Meyer B, Kraft V, Kaspareit J. An enzyme-linked immunosorbent assay (ELISA) for the detection of antibodies to Pasteurella pneumotropica in murine colonies. Lab Anim Sci. 1988;38(1):37-41.

13. Boot R, Thuis HC, Veenema JL, Bakker RG. An enzyme-linked immunosorbent assay (ELISA) for monitoring rodent colonies for Pasteurella pneumotropica antibodies. Lab Anim. 1995;29:307-13.

14. Manning PJ, Gaibor J, Delong D, Gunther R. Enzyme-linked immunosorbent assay and immunoblot analysis of the immunoglobulin $\mathrm{G}$ response to whole-cell and lipooligosaccharide antigens of Pasteurella pneumotropica in laboratory mice with latent pasteurellosis. J Clin Microbiol. 1989;27(10):2190-4.

15. Manning PJ, DeLong D, Gunther R, Swanson D. An enzyme-linekd immunosorbent assay for detection of chronic subclinical Pasteurella pneumotropica infection in mice. Lab Anim Sci. 1991;41(2):162-5.

16. See SB, Thomas WR. Protective anti-outer membrane protein immunity against Pasteurella pneumotropica infection of mice. Microbes Infect. 2013;15:470-9.

17. Sasaki H, Ishikawa $H$, Sato $T$, Sekiguchi $S$, Amao H, Kawamoto E, et al. Molecular and virulence characteristics of an outer membrane-associated RTX exoprotein in Pasteurella pneumotropica. BMC Microbiol. 2011;11:55.

18. Sasaki H, Ishikawa H, Kojima K, Itoh M, Matsumoto T, Itoh T, et al. Intranasal immunization with a non-adjuvanted adhesive protein descended from Pasteurella pneumotropica and its preventive efficacy against opportunistic infection in mice. Vaccine. 2013;31(48):5729-35.

19. Benga L, Benten WPM, Engelhardt E, Christensen H, Sager M. Analysis of 16S-23S rRNA internal transcribed spacer regions in Pasteurellaceae isolated from laboratory rodents. J Microbiol Methods. 2012;90:342-9.

20. Benga L, Sager M, Christensen H. From the [Pasteurella] pneumotropica complex to Rodentibacter spp.: an update on [Pasteurella] pneumotropica. Vet Microbiol. 2018;217:121-34. 
21. Boot R, Thuis HCW, Veenema JL, Bakker RGH. An enzyme-linked immunosorbent assay (ELISA) for monitoring rodent colonies for Pasteurella pneumotropica antibodies. Lab Anim. 1995;29:307-13.

22. Ganfield DJ, Rebers PA, Heddleston KL. Immunogenic and toxic properties of a purified lipopolysaccharide-protein complex from Pasteurella multocida. Infect Immun. 1976;14(4):990-9.

23. Cary CJ, Peter GK, Chrisp CE, Keren DF. Serological analysis of five serotypes of Pasteurella multocida of rabbit origin by use of an enzyme-linked immunosorbent assay with lipopolysaccharide as antigen. J Clin Microbiol. 1984;20(2):191-4.

24. Wijewardana TG, Wilson CF, Gilmour NJL, Poxton IR. Production of mouse monoclonal antibodies to Pasteurella multocida type a and the immunological properties of a protective anti-lipopolysaccharide antibody. J Med Microbiol. 1990;33:217-22.

25. Sasaki $H$, Ishikawa $H$, Terayama $H$, Asano $R$, Kawamoto $E$, Ishibashi $H$, et al. Identification of a virulence determinant that is conserved in the Jawetz and Heyl biotypes of [Pasteurella] pneumotropica. Pathog Dis. 2016;74(6):2016-9.

26. Hoiczyk E, Roggenkamp A, Reichenbecher M, Lupas A, Heesemann J. Structure and sequence analysis of Yersinia YadA and Moraxella UspAs reveal a novel class of adhesins. EMBO J. 2000;19(22):5989-99.

27. Yu NY, Wagner JR, Laird MR, Melli G, Rey S, Lo R, et al. PSORTb 3.0: improved protein subcellular localization prediction with refined localization subcategories and predictive capabilities for all prokaryotes. Bioinformatics. 2010;26(13):1608-15

28. Juncker A, Willenbrock $H$, von Heijne G, Brunak S, Nielsen $H$, Krogh A. Prediction of lipoprotein signal peptides in gram negative bacteria. Protein Sci. 2003;12:1652-62.

29. Fornefett J, Krause J, Klose K, Fingas F, Hassert R, Eisenberg T, et al. Comparative analysis of clinics, pathologies and immune responses in BALB/C and C57BL/6 mice infected with Streptobacillus moniliformis. Microbes Infect. 2017;20:101-10.

30. Filip C, Fletcher G, Wulff JL, Earhart CF. Solubilization of the cytoplasmic membrane of Escherichia coli by the ionic detergent sodium-lauryl sarcosinate. J Bacteriol. 1973;115(3):717-22.

31. Fingas $F$, Volke $D$, Bielefeldt $P$, Hassert R, Hoffmann R. Detection of mammalian orthoreovirus type-3 ( Reo-3 ) infections in mice based on serotype-specific hemagglutination protein sigma-1. Virol J. 2018;15(114):1-11.

32. Sedmak JJ, Grossberg SE. A rapid, sensitive, and versatile assay for protein using Coomassie brilliant blue G250. Anal Biochem. 1977;79:544-52.

33. Neuhoff V, Stamm R, Eibl H. Clear background and highly sensitive protein staining with Coomassie blue dyes in polyacrylamide gels: a systematic analysis. Electrophoresis. 1985;6(9):427-48.

34. Andreasson U, Perret-Liaudet A, van Doorn LC WW, Blennow K, Chiasserin $D$, Engelborghs $S$, et al. A practical guide to immunoassay method validation. Front Neurol. 2015;6:1-8.

35. Zhang Z, Schwartz S, Wagner L, Miller W. A greedy algorithm for aligning DNA sequences. J Comput Biol. 2000;7(1-2):203-14.

Ready to submit your research? Choose BMC and benefit from:

- fast, convenient online submission

- thorough peer review by experienced researchers in your field

- rapid publication on acceptance

- support for research data, including large and complex data types

- gold Open Access which fosters wider collaboration and increased citations

- maximum visibility for your research: over $100 \mathrm{M}$ website views per year

At BMC, research is always in progress.

Learn more biomedcentral.com/submissions 